\title{
The capacity market and its impact on the development of distributed energy sources
}

ABSTRACT: The condition of the Polish energy sector does not inspire any trust of its customers. Outdated machinery and the lack of investment in new technologies make it necessary to take action to ensure the stability and continuity of electricity supplies to the end-user. In Poland, the industrial power sector is based on the use of coal and despite the Government's announcements to resign from this raw material, more and more power investments are being made to generate energy from coal (Ostrołęka power plant). The solution which compensates for the current state of the Polish power industry is the development of distributed generation. The article presents a description of dispersed sources, power market, its organization and problems arising from its implementation. Distributed energy sources in the form of micro installations, energy clusters and virtual power plants have been described and characterized as well. It also assesses the impact of power market introduction on the development of distributed energy sources.

The impact of the power market on the development of distributed sources is very hard to predict and determine. The functioning and further development of the energy sector, including the capacity market, strongly depends on the laws, regulations, as well as the economic and political situation in Poland and Europe. The social factor will also play an important role as the introduction of the capacity market will burden the financial side of each energy consumer. On the basis of the data

$\triangle$ Corresponding Author: Sławomir Sowa; e-mail: Slawomir@sowa.poznan.pl

1 University of Technology Poznań, Electric Power Engineering, Faculty of Electrical Engineering; ORCID iD: 0000-0001-9030-7185; e-mail: Slawomir@sowa.poznan.pl

2019. The Author(s). This is an open-access article distributed under the terms of the Creative Commons Attribution-ShareAlike International License (CC BY-SA 4.0, http://creativecommons.org/licenses/by-sa/4.0/), which permits use, distribution, and reproduction in any medium, provided that the Article is properly cited. 
presented on particular sources and distributed systems, one can only make predictions related to the possible effects of introducing the capacity market for the development of distributed sources.

KEYWORDS: capacity market, distributed energy sources, renewable energy sources, energy market, energy clusters

\section{Introduction}

For a long time, there has been an ongoing discussion on the development of the energy sector both at the government level and in the media concerning the future of the national energy system. The most common issue of recent years is the capacity market. Its implementation has a considerable impact on the safety of the electricity supply. The Energy Department, as the institution responsible for the power market, assumes that the implementation of the power market will guarantee the long-term stability of electricity supplies to both the industry and individual consumers. The new model of the power system organization assumes that apart from energy, which is considered as a "commodity", it is also important to note that producers are ready to provide a certain amount of power for the power system (Chmielniak et al. 2016). In Poland, it is necessary to invest in new generation capacities. This is caused by a growing demand for electricity and outdated generation units. One of the possible solutions may be renewable energy sources. The high unpredictability of energy generation, which is strongly dependent on weather conditions, means that RES are unable to ensure stability in the power system.

Energy generated from renewable sources has priority to introduce it into the power grid. It limits the actual working time of fully controllable conventional power generation units working in the power system.

It also forces the necessity to keep these units in constant readiness for use in the event of the lack of generation from renewable sources. The solution that could guarantee the supply of energy when there is no energy generation is energy storage. In order to develop an efficient and relatively inexpensive technology, intensive work is underway in this area. The efficient use of energy storage facilities is only planned for about 10 years from now (Krupa et al. 2018).

The problem with the proper power balance is observed in most European Union countries (Michalski and Soltysik 2016). It is expected that the power market will guarantee a proper balance between the consumers' demand for electricity and the volume generated by the generators. The question is whether and how the power market will affect the development of distributed systems.

The article presents the nature of the power market, its organization and problems caused by its implementation. The article describes and characterizes distributed energy sources in the form of micro installations, energy clusters and virtual power stations. It also evaluates the influence of power market introduction on the development of distributed energy sources. 


\section{The capacity market}

The capacity market was introduced in Poland under the Act of 8 December 2017 (URM 2017). The reason for this decision was the need to develop a long-term outlook to encourage further investment in new power generation capacities, especially at a time of low profitability in the manufacturing sector.

One of the main reasons that affected the profitability of the system energy sector in Europe was the dynamic development of renewable energy systems (Szczerbowski and Ceran 2013). Considering the energy mix and network topology, the most effective guarantee of energy supply in Poland is the Power generation sector (Grabara and Kucęba 2011). The Energy Act introduces the mechanisms which allow the power balance to be regulated in periods of particularly high demand for energy, as well as in periods when, due to weather conditions or various technical reasons, part of the power in the NPS is temporarily unavailable. In addition, the regulations of the Act are to ensure the profitability of the investments which will guarantee the increase of production capacity ensuring long-term work on the basis of energy demand. The capacity market introduces fees for energy generating units, for instructions specified in the agreement, generating capacity, which may be used in the event of energy deficiency from other sources or increased demand for energy from customers. The participation in the capacity market is allowed for capacities located in the power systems of the Member States of the European Union whose power systems are directly connected to the NPS. The future of the capacity market at European Union level is uncertain, which is why it is necessary to work on the reform of the balancing market, or rather on improving its flexibility.

\subsection{The capacity market and its structure}

The implementation of the capacity market is classified as public aid and requires prior notification and approval of the European Commission. Within the framework of the power market mechanism, power agreements will be concluded under which the so-called power producers will be obliged to deliver appropriate power to the NPS during periods of crisis and to be prepared to deliver it. Obligations, determined by the capacity obligation, will be offered during the auctions by the producers, operators of energy storage facilities and controlled electricity consumers, as well as by entities representing groups of producers or consumers. Power auctions will take place within a specified period of time before the date on which power suppliers will offer their products. The duty of annual participation in the auctions applies to all owners of an existing power generation unit with a gross achievable capacity of not less than 2 MW. Entry is voluntary for other generating units willing to participate in the power market processes. Performed certification is intended to register the capacity of natural units and units of planned 
demand reduction (Demand Side Response - DSR) in the market registry. DSR is a service of the voluntary and temporary reduction of electricity consumption by consumers or postponing its use in time in return for expected remuneration. The Capacity Market Register is an electronic platform that gathers, processes and exchanges data related to trading, settlement and technical matters related to the power market.

The total net achievable power of all existing physical units registered in the register equals 37,267.44 GW. It also includes planned generation capacities which reach 14,587.1 GW.

A summary of all existing and future power generation units by type of basic fuel is shown in Table 1.

At the beginning of January 2019 a new general certification took place within the capacity market. In comparison to 2018 , the total available capacities entered in the system grew to $7.3 \mathrm{GW}$.

TABLE 1. Generating units participating in main auctions

TABELA 1. Jednostki wytwórcze biorące udział w aukcjach głównych

\begin{tabular}{|l|c|c|l|c|c|}
\hline \multicolumn{7}{|c|}{ Generation units } \\
\hline & Quantity [pcs.] & Power [MW] & & \multicolumn{2}{c|}{ Planning } \\
\hline Conventional & 248 & $29,416.40$ & Conventional & 56 & $8,894.5$ \\
\hline RES & 634 & $6,312.51$ & RES & 48 & 69.6 \\
\hline $\begin{array}{l}\text { Energy } \\
\text { magazines }\end{array}$ & 18 & $1,538.53$ & $\begin{array}{l}\text { Energy } \\
\text { magazines }\end{array}$ & 15 & $5,623.0$ \\
\hline Total & 900 & $37,267.44$ & Total & 119 & $14,587.1$ \\
\hline
\end{tabular}

Source: PSE data.

Among the existing generation units, the dominant ones are conventional coal-fired power plants with a total generating capacity of $26.28 \mathrm{GW}$ net, representing $70.2 \%$ of the total registered capacity of all units. Wind power plants with a total net achievable capacity of $5.08 \mathrm{GW}$ play a significant role in the group of renewable energy sources. Sadly, due to negative legislative provisions, no increase of registered capacity is planned in this sector.

The structure of existing generation capacities by the basic fuel type is presented in Figure 1.

The owner and the managing organ of the platform is the Polish Transmission System Operator.

In a further stage, the following activities related to the power market (URM 2017) are planned for 2019:

$\checkmark$ by March 1, 2019 - announcement of the main auction dates for 2024 and additional auction dates for 2024 ,

- March 8-completion of general certification, 
$\downarrow 14$ weeks before the main auction - Commencement of additional auction certification for 2024,

$\downarrow$ II/IV quarter of year 2019 - Beginning of the certification for additional auctions for 2021,

$\downarrow 4$ weeks before the main auction - completion of the certification for the main auction for 2024 ,

$\checkmark$ December 12, 2019 - Main auction for 2024.

The largest group of units entered in the register consists of units with net achievable power ranging from 2 to $10 \mathrm{MW}$. On the other hand, the group with the maximum achievable net power is the group composed of units with power exceeding $200 \mathrm{MW}$.

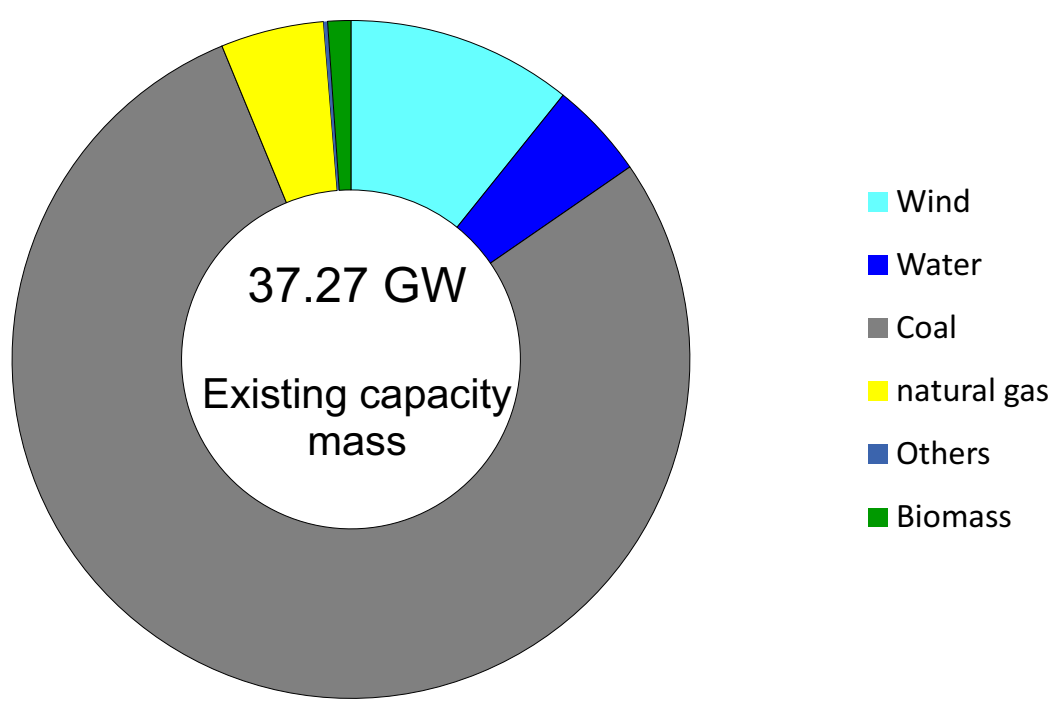

Fig. 1. The market share of net achievable capacity of installed generation units by the type of primary energy (own study based on PSE and EU data)

Rys. 1. Udział w rynku mocy osiągalnych mocy netto istniejących jednostek wytwórczych ze względu na rodzaj energii pierwotnej

The main auction for the year 2020 was won by 120 bids from power suppliers. In total, for the delivery year 2022, power contracts for 23,038.875 MW (IPURE) were concluded.

\subsection{The consequences of implementing the capacity market}

The main goal and intention of implementing the power market is to ensure stability of energy supply for consumers and to reduce the risk of blackouts (Korab et al. 2016). Achieving such objectives requires investment in the modernization of the obsolete power generation sector and 
the construction of new power generation units to ensure a sustainable energy supply. All of these measures require a very high financial effort. The Ministry of Energy estimates that the cost of capacity market maintenance will amount to PLN 2-3 billion. A high part of these costs will be covered by customers in the form of an additional capacity fee. The adopted Act (URM 2017) includes regulations in order to guarantee power resources adequate for the needs of electricity generation sources.

According to the Act, from January 2021 consumers will pay an additional power fee, which will be included in the energy bills. The lack of proper legal regulations and the non-implementation of the capacity market could cause serious problems in the supply of electricity in the nearest future.

The introduction of the capacity market means a transformation of the energy sector. Not only will the generated energy be subject to sale purchase transactions, but also the willingness to supply sufficient power to the grid, i.e. the so-called net available power. In these areas, the power grid was usually not prepared to connect generating units. Systems operating in the distributed generation are not centrally disposable. The power market is also linked to $\mathrm{CO}_{2}$ emissions from coal-fired power plants. The Polish Government has sought a provision in the European Parliament concerning the introduction of a $\mathrm{CO}_{2}$ emission limit for power plants supported by public funds within the power market.

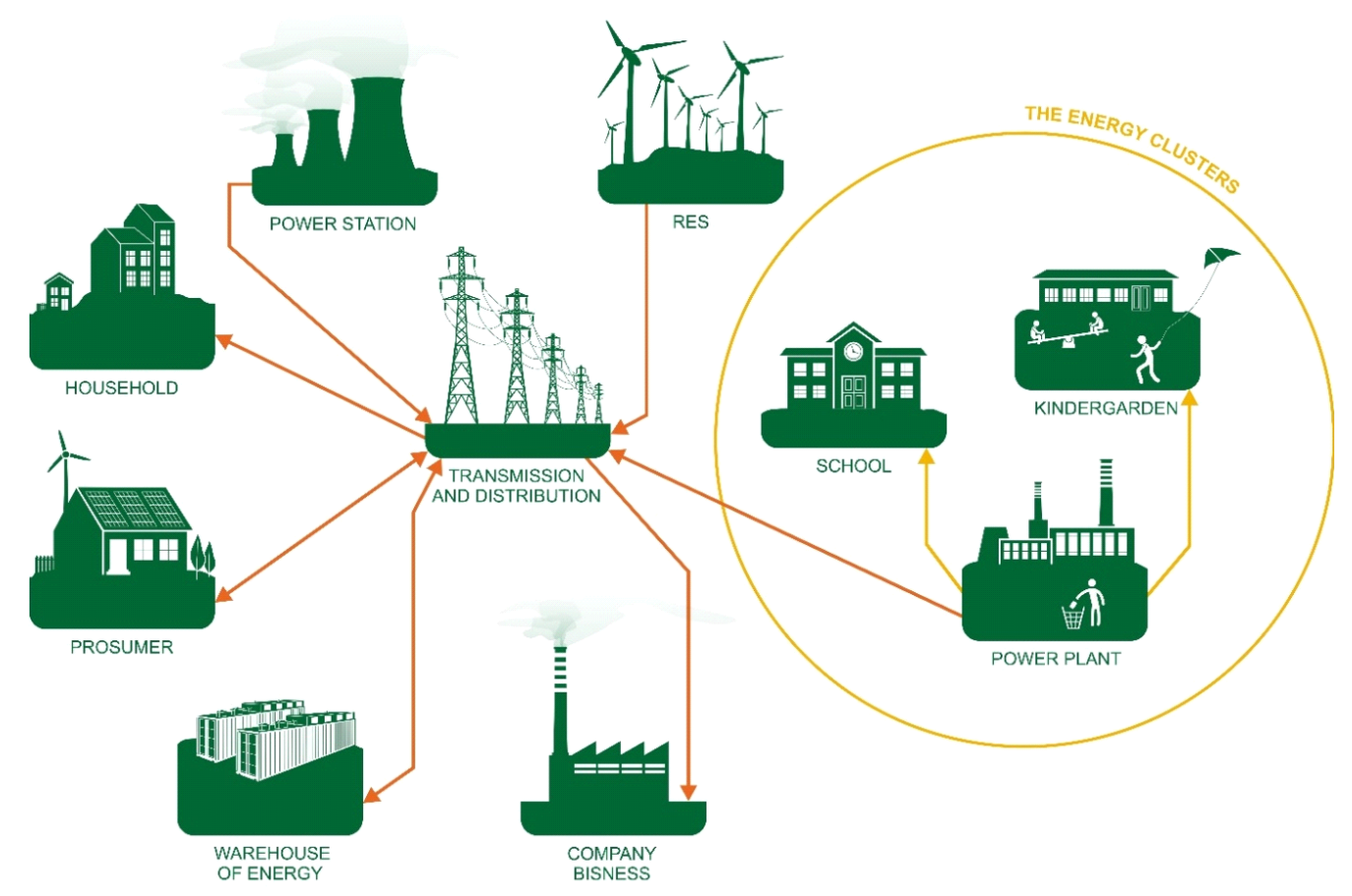

Fig. 2. Energy market scheme including energy clusters

Rys. 2. Schemat rynku energii z uwzględnieniem klastrów energii 
Finally, a compromise agreement was adopted under which new power plants emitting more than $550 \mathrm{~g}$ of $\mathrm{CO}_{2}$ per kilowatt hour of electricity and those which will start operating commercially after the entry into force of the regulation will not be able to participate in the mechanisms related to the power market. This means that they will not be able to use government subsidies.

Power plants with power units which do not meet these requirements will be able to participate in these support mechanisms until July 1, 2025. This will mean that financial support for the coal-based Polish power industry will only be possible until the above-mentioned date of July $1,2025$.

The power market should provide the required funds that can be used to create new investments, supporting the construction of new power generation capacities, the modernization of existing ones as well as the rebuilding and replacement of withdrawn capacities. The potential risks related to the proper functioning of the program are only related to the legislation of the Energy Office. It may have an impact on the admission of the relevant technologies to the capacity market.

\section{Diffuse sources characteristics}

Recently, one of the most visible trends in the world economy, which enables the effective management of raw materials and local energy resources, is the development of distributed energy. Distributed generation can be simply defined as generation of energy by autonomous systems located near the customer. These are usually small units or manufacturing facilities with a rated output of 50-150 MW (Paska 2017). In these areas, the power grid was usually not prepared to connect generating units. Systems operating in the distributed generation are not centrally disposable. Technological development, far-reaching changes in the area of organization, financing and new environmental policy were the factors that directly influenced the development of distributed energy sources, especially micro installations. The analyses and forecasts show that the generation of energy in distributed sources may be an important part of the energy supply complement system, especially in less urbanized areas.

The distributed power generation of small capacities is being developed in the area of generating units using fossil fuels, e.g. natural gas. A second group consists of highly developing systems based on renewable energy sources. Another group, which is still in the process of development, are units based on energy generation using fuel cells, i.e. hydrogen and methanol. Renewable power plants progressively replace the technologically that is obsolete in conventional power plants. The fact that there are no new investments in the conventional energy sector is related both to environmental care and, above all, to the fact that there is no guaranteed return on investment. Investments in the subsidized market, that is, renewable energy, guarantee a return on investment within a specified period of time. It is the attractiveness of costs that is a key factor in the competitiveness of distributed generation. As the various calculations show, the costs of 
delivering energy from the distributed generation are lower than the costs of energy generated in centralized units (Sowiński 2014). Hybrid systems, supported by smart energy management systems, deliver power in various weather conditions, which have a significant impact on the amount of energy generated (Sowa 2018). The International IRENA Agency report shows that there is a continuous increase in power from renewable energy sources in Poland from $3.4 \mathrm{GW}$ in 2010 to $10.6 \mathrm{GW}$ in 2020. According to forecast in 2030, Poland may reach even $28.3 \mathrm{GW}$ from RES (IRENA 2015). The highest growth rate is expected in the area of solar energy, while the highest slowdown is observed in the wind energy sector. This is a consequence of the act introduced by the Polish government, as a result of which many areas have been excluded from the possibility of installing new wind power plants.

\subsection{The energy clusters}

The idea of energy clusters was introduced in 2016 and its goal is to develop distributed energy, which at the same time will improve energy security and increase economic efficiency. According to the Law on Renewable Energy Sources (UOZE 2015), an energy cluster can be defined as a consensual civil-law agreement between local entities involved in the production, consumption, storage and sale of: electricity, heat, cold, electricity in transport and fuels. Clusters work within a distribution network with a rated voltage lower than $110 \mathrm{kV}$, in an area that does not exceed the territory of one county or 5 municipalities. The area of activity of an energy cluster is determined on the basis of the location of a connection of energy producers and consumers who are members of a given cluster. The Energy Department organizes competitions in which qualified clusters are awarded with energy department certificates. In the most recent competition for energy clusters resolved at the end of 2018, 33 clusters from 13 voivodships received the Pilot Energy Cluster Certificate. Altogether, the auctions selected 66 functioning energy clusters. A map of the location of certified energy clusters is presented in Figure 2. Clusters were presented on the map with the division into I and II Competition and those that were distinguished.

As it was mentioned before, the aim of energy clusters is to develop distributed energy. Their goal is to ensure the improvement of local energy security in a way that guarantees economic efficiency while having a beneficial impact on the environment. The local nature of the cluster results from the fact that although they cooperate with the NES, they remain autonomous. They do not require connection to the high voltage grid and the energy they generate is transmitted over short distances. The energy clusters enable the use of local resources and potential of the domestic energy sector. They support the implementation of the latest technologies in places where they are needed and economically justified (Kim and Thottan 2011). For this reason, the effectiveness of energy clusters depends on rational and effective use of potential: locally available energy resources, renewable energy sources, innovation, entrepreneurship in the area of generation, distribution, transmission and management of energy consumption. 


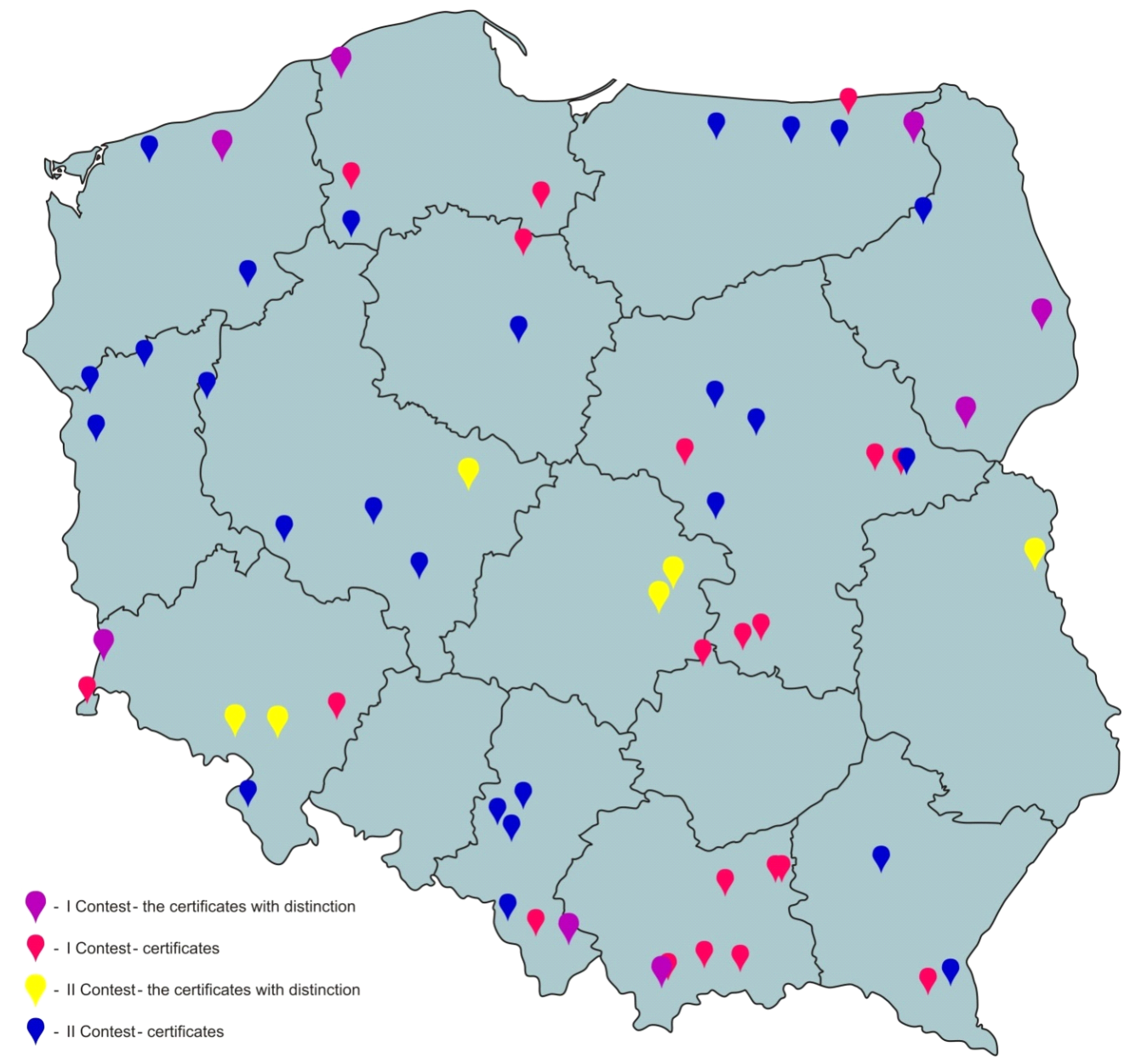

Fig. 3. The location of energy clusters in Poland (own study)

Rys. 3. Lokalizacja klastrów energii w Polsce

Energy clusters provide the development of distributed energy and improve local energy security while maximizing economic efficiency. Energy clusters are an innovative solution with no counterpart in Europe. The energy market scheme, which also includes energy clusters, is presented in Figure 5. 


\subsection{Virtual power plants}

Virtual power plants are another alternative to the centralized generation systems, which are becoming increasingly obsolete and inefficient (Szczerbowski 2015). The functioning of virtual power plants is based on remote management using intelligent ICT systems, which combine distributed renewable energy, energy storage and end users. Advanced energy management systems are responsible for the development of virtual power plants. Such an IT system is able to manage the energy of a specific separated network and also operate on a national scale. A virtual power plant, which is an IT platform, makes it possible for electricity producers and suppliers to control the power consumption of end users, such as small businesses or households. The increase in the use of renewable energy sources has a negative impact on the stability of the power system.

The interconnection of thousands of generators, energy users, energy storage facilities and the ICT network enables monitoring the energy flow and effective energy management. The PPS must be able to constantly monitor the operation of a virtual power plant. This means that IT systems of virtual power plants must be integrated with IT resources of the NPS (Szczerbowski 2011). The general concept of virtual power plant operation is presented in Figure 4.

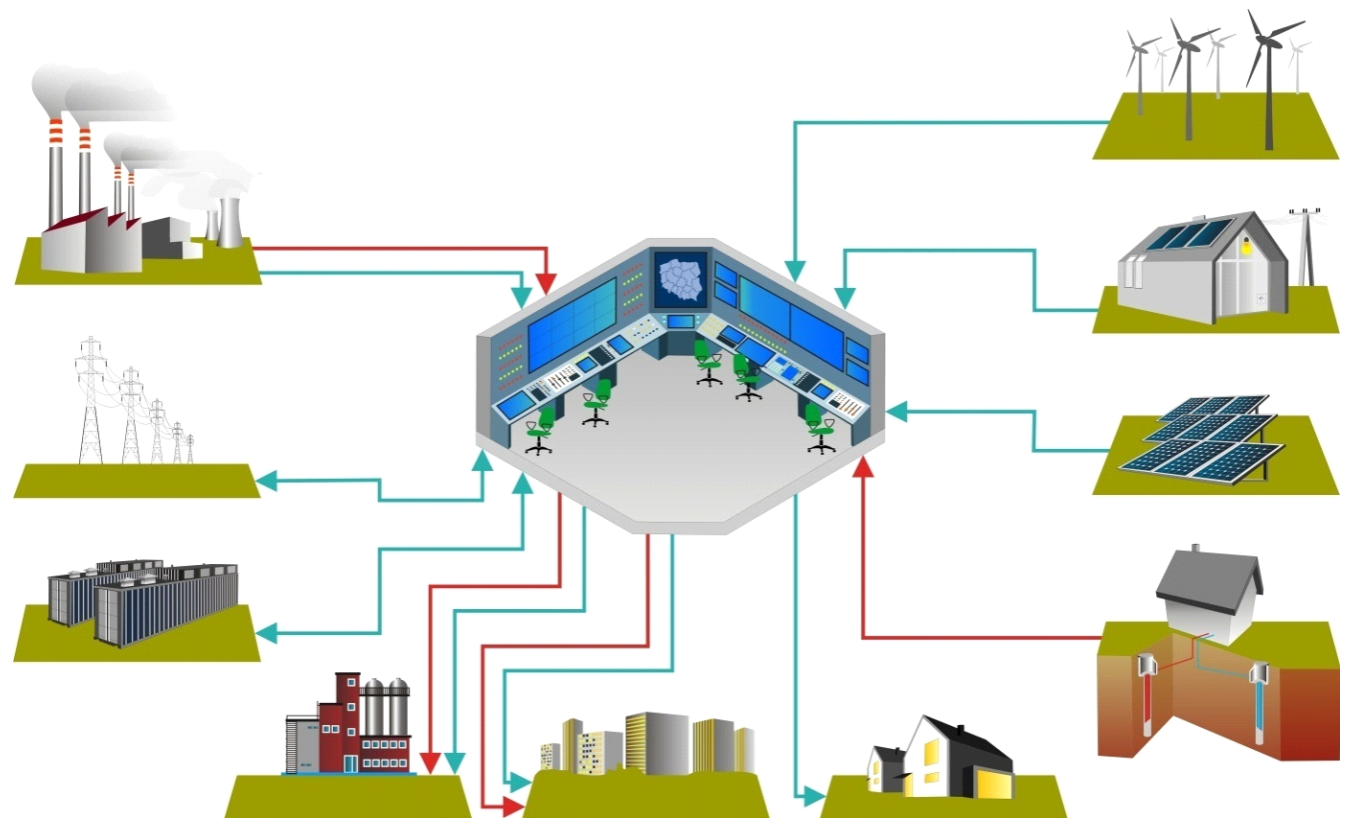

Fig. 4. Functional concept of a virtual power plant (own study)

Rys. 4. Koncepcja funkcjonalna wirtualnej elektrowni

The advantages of virtual power plants are not limited to the decentralization of electricity sources. The most important potential of this technology is the possibility to create an advanced IT network that analyzes customers' energy demands in real time and adjusts to their needs. 


\subsection{A prospective cloud of energy}

The energy market is under constant change and transformation. The observable changes apply to both energy producers and consumers. Energy producers are forced to adjust their operating modes to the increase in energy consumption by end users and to the orientation towards the use of pro-ecological energy generation technologies. Changes that appear on the market of energy suppliers and consumers force the new solutions of coordinating the functioning of the energy market and power systems for different developmental options. In its concept, the energy cloud assumes that the power system is a virtual electricity storage with the free access of each participant of the system (Rzepka et al. 2017).

In practice, the use of a prosumer's energy cloud means registering the amount of electricity introduced by a microinstallation into the power system and the amount of energy consumed by this prosumer. It is one of the proposed services provided by network operators to prosumers. Embracing the idea of a prosumer's energy cloud, it is assumed that it will be characterized by technological openness (possibility of connecting micro installations of any power and technology) and universal access to network infrastructure.

The idea of a prosumer's cloud of energy is presented in Figure 5.

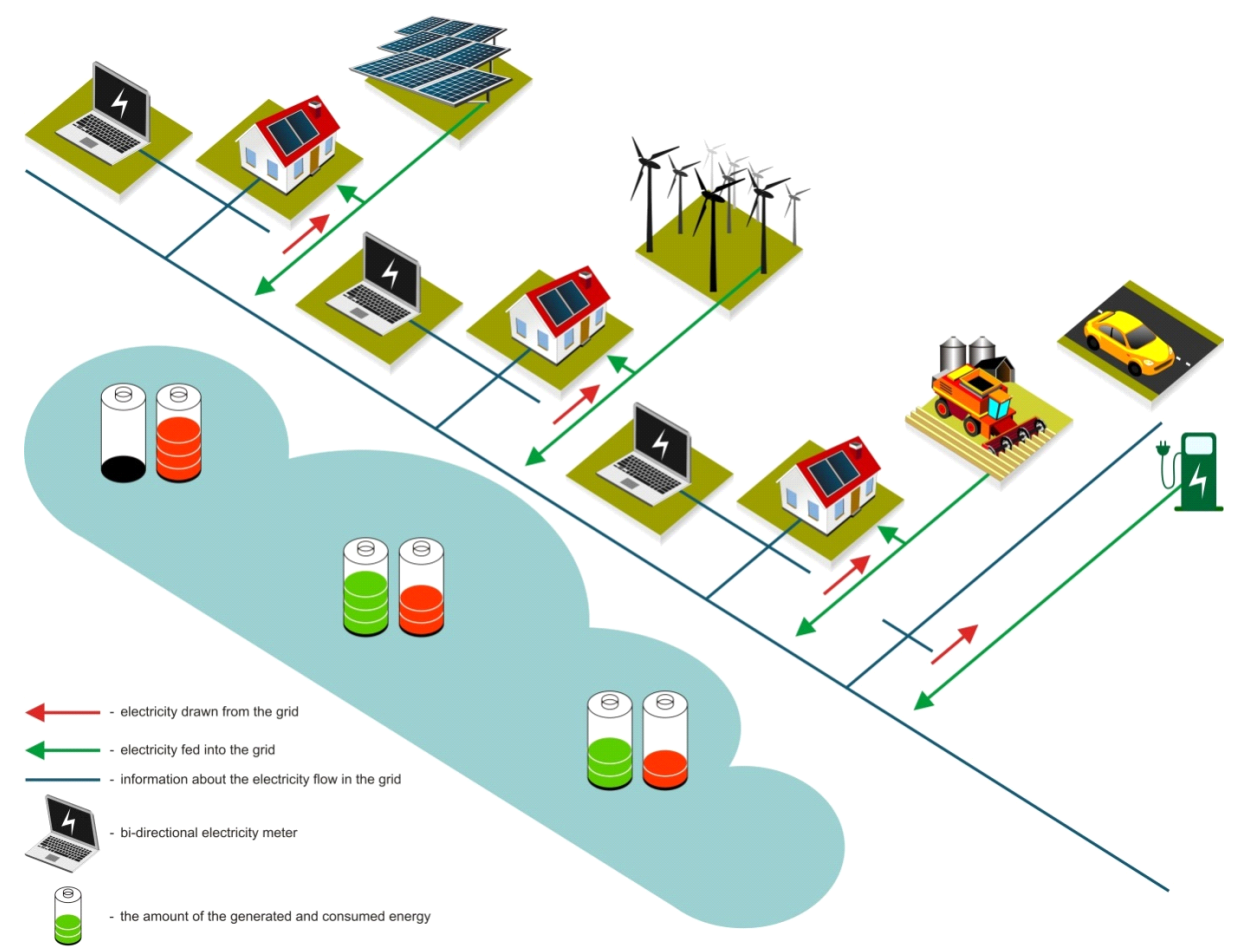

Fig. 5. The idea of a prosumer's cloud of energy (own study)

Rys. 5. Koncepcja funkcjonalna chmury energii 


\section{Summary}

The national energy system in Poland has to be modernized. Power plants, combined heat and power plants and the transmission networks are waiting for renovations and upgrades. The energy sector will also have to face new challenges, such as electromobility, factory and workplace automation. The future, which will gradually come into life, belongs to the distributed energy sector, which will be controlled by virtual power plants. Their responsibility will be to securely deliver the required energy to the national energy system at the right time.

Electricity is not a commodity that can be easily and freely disposed of. Both the balance of demand and supply of electricity in the NPS is a critical factor. That is why it is so important to maintain a proper balance of the power system operation at any time during the operation of the PPS.

The power market is able to ensure a long-term stable supply of electricity to households and industry. As a result, every energy user throughout the country will have the possibility to use electricity with time and in quantities based on their needs. The development of distributed systems should be supported by Polish legislation. For this purpose, it is necessary to thoroughly examine the problems and barriers that prevent the free development of this manufacturing sector.

The article describes the solutions such as energy clusters, virtual power plants and a prosumer's energy cloud.The aim of energy clusters is to develop distributed energy. Their main task is to ensure and improve local energy security in a way that guarantees economic efficiency and at the same time has a positive impact on the environment. The main difficulty in the development of energy clusters is the lack of financial resources and low awareness of the direction, vision of development and functioning of such systems.

With very few exceptions, energy clusters do not have their own transmission lines. Using the infrastructure of different operators is necessary, which significantly hampers the functioning of energy clusters. The implementation of a decentralized model of distributed energy sources can minimize the need for large investments in new power generation sources and the development of the power grid.

The establishment of the capacity market was first and foremost aimed at ensuring security and stability of the energy supply. This is an important aspect and a major benefit. However, there is a downside to the costs, most of which will have to be covered by producers and consumers.

According to the Power Market Act, each household will pay an additional PLN 10 per month to the bill (the so-called Power Fee). Assuming that significant forms of support for the initiatives of micro RES installations will appear and prices of new, efficient technologies of energy production from renewable sources will decrease, a constant increase in the share of RES in the total energy production can be predicted. The same applies to small distributed installations, which are becoming more and more popular. Owning a RES installation, apart from being environmentally conscious and being able to obtain free energy, ensures independence from external energy suppliers. The capacity market has probably triggered and revived interest in re- 
newable energy sources, which in itself are an important element influencing the improvement of energy efficiency. They also ensure a certain independence from external energy supplies, which may prevent the owners of such installations from unexpected interruptions in the energy supply, limiting their capacity, consumption or price increases. The energy clusters described in the article will contribute to the improvement of local energy security. The formation and functioning of local energy clusters has another big advantage. It has an important impact on the improvement of social awareness in the production of green energy.

Distributed source systems can be perceived as a threat to distribution companies and power producers. However, as a consequence, the development of distributed energy has much more benefits not only for the consumers but also for the energy distributors. It may be assumed that the introduction of the capacity market will not slow down the development of distributed source systems and in some cases will even stimulate the development of new ones.

\section{References}

CHMielniaK et al. 2016 - ChMiELNiAK, T., RUsin, A. and ŁukOwiCZ, H. 2016. The modernization and revitalization of existing coal - fired plants are an important requirement for the stability of the electricity generation sector (Modernizacja i rewitalizacja istniejacych elektrowni węglowych jako ważny wymóg stabilności sektora wytwarzania energii elektrycznej). Polityka Energetyczna - Energy Policy Journal Vol. 19, Iss. 3, pp. 49-60 (in Polish).

GRABARA, J. and KUCĘBA, R. 2011. Systemic administration of the final energy value chain in the light of energy security (Systematyczne zarzadzanie końcowym łańcuchem wartości energetycznej $w$ świetle bezpieczeństwa energetycznego). Rynek Energii 5, pp. 20-23 (in Polish).

IPURE - Informtion from the President of the Energy Regulatory Office (Informacja Prezesa Urzędu Regulacji Energetyki). Nr 103/2018, on 14 December 2018 (in Polish).

IRENA 2015. International Renewable Energy Agency. REmap 2030: Renewable Energy Prospects for Poland (Perspektywy energetyki odnawialnej dla Polski) (in Polish).

KIM, H. and THOTTAN, M. 2011. A two-stage market model for microgrid power transactions via aggregators (Dwustopniowy model rynkowy dla mikro-energetycznych transakcji sieciowych za pośrednictwem agregatorów). BellLabs Technical Journal Vol. 16, pp. 101-107 (in Polish).

Korab et al. 2016 - KorAB, R., JAWORSKi, W., WAWrZYNIAK, K., JAKUBEK, M. and KrólikowsKi, K. 2016. Zarządzanie systemem elektroenergetycznym w zagrożeniowych stanach pracy (Management of the power system in dangerous working conditions). Rynek Energii 4 (in Polish).

KrUPA et al. 2018 - KRUPA, K., NIERADKO, Ł. and HARAZIŃSKI, A. 2018. Prospects for energy storage in the world and in Poland in the 2030 horizon (Perspektywy rozwoju magazynowania energii elektrycznejna świecie $i w$ Polsce $w$ horyzoncie roku 2030). Polityka Energetyczna - Energy Policy Journal Vol. 21, Iss. 2, pp. 19-34.

Michalski, D. and SoŁTYsiK, M. 2016. The Next Step in Development of European Power Market Capacity Market (Rynek mocy. Kolejny etap tworzenia zliberalizowanego rynku energii elektrycznej w Unii Europejskiej) Unia Europejska.pl, 3/2016, pp. 49-60 (in Polish).

PASKA, J. 2017. Distributed energy sources (Rozproszone źródta energii). Warszawa: OWPW (in Polish).

RZEPKA et al. 2017 - RZEPKA, P., SOŁTYSIK, M. and SZABLICKI, M. 2017. Energy cloud - a new service for prosumers (Prosumencka chmura energii - koncepcja nowej uslugi dla Prosumentów). Zeszyty naukowe Instytutu Gospodarki Surowcami Mineralnymi i Energii PAN No. 98, pp. 177-186 (in Polish). 
SOwA, S. 2018. Increasing the energy efficiency of hybrid RES installations using KNX system. Renewable Energy Sources: Engineering, Technology, Innovation, Springer, pp. 387-394.

SowIŃSKI, J. 2014. Cost of electricity from renewable energy sources. Przeglad Elektrotechniczny 8, pp. $127-131$.

SzCZERBOWSKI, R. 2011. Decentralized Energy Generation and Smart Grid - Virtual Power Plant (Generacja rozproszona oraz sieci Smart Grid). Polityka Energetyczna - Energy Policy Journal Vol. 14, Iss. 2, pp. 391-404 (in Polish).

SZCZERBOWSKI, R. 2015. Selected European countries energy policy and the Polish energy strategy (Polityka energetyczna wybranych krajów europejskich a strategia energetyczna Polski). Polityka Energetyczna - Energy Policy Journal Vol. 18, Iss. 3, pp. 5-15 (in Polish).

SZCZERBOWSKI, R. and CERAN, B. 2013. Small scale, distributed power generation based on renewable energy sources - possibilities for development, cost of electricity production, and technical problems (Możliwości rozwoju i problemy techniczne matej generacji rozproszonej opartej na odnawialnych źródtach energii). Polityka Energetyczna - Energy Policy Journal Vol. 6, Iss. 3, pp. 193-205 (in Polish).

UOZE 2015. The Act on Renewable Energy Sources (Ustawa o odnawialnych źródtach energii). Journal of Laws RP on 20 February 2015, poz. 478, Warszawa (in Polish).

URM 2017. The Capacity Market Act (Ustawa o rynku mocy). Journal of Laws RP on December 2017, poz. 9, Warszawa (in Polish)

Sławomir SowA

\section{Wpływ rynku mocy na rozwój źródeł rozproszonych}

\section{Streszczenie}

Stan polskiej energetyki nie budzi zaufania odbiorców. Przestarzały park maszynowy, brak inwestycji w nowe technologie sprawiają, że istnieje potrzeba podejmowania działań mających na celu zapewnienie stabilności i ciągłości dostaw energii elektrycznej do odbiorcy końcowego. W Polsce energetyka zawodowa oparta jest na węglu i pomimo zapowiedzi rządowych, że będziemy odchodzić od tego surowca, to tworzone są kolejne inwestycje energetyczne wytwarzające energię z węgla (elektrownia Ostrołęka). Rozwiązaniem rekompensującym istniejący stan w polskiej energetyce jest rozwój generacji źródeł rozproszonych. W artykule scharakteryzowano źródła rozproszone, rynek mocy, przedstawiono jego organizację oraz problemy wynikające z jego wdrożenia. Opisano i scharakteryzowano rozproszone źródła energii w postaci mikroinstalacji, klastrów energetycznych oraz wirtualnych elektrowni. Dokonano także oceny wpływu wprowadzenia rynku mocy na rozwój rozproszonych źródeł energii.

Wpływ rynku mocy na rozwój źródeł rozproszonych jest trudny do przewidzenia i określenia. Funkcjonowanie i rozwój sektora energetycznego w tym rynku energii w dużej mierze uzależnione jest od przepisów, uregulowań prawnych oraz sytuacji gospodarczo-politycznej Polski 
oraz Europy. Czynnik społeczny będzie także odgrywał istotną rolę, gdyż wprowadzenie rynku mocy będzie obciążało od strony finansowej każdego odbiorcę energii. Na podstawie przedstawionych informacji o poszczególnych źródłach i systemach rozproszonych, można jedynie dokonać przewidywań związanych z ewentualnymi skutkami wprowadzenia rynku mocy dla rozwoju źródeł rozproszonych.

SŁOWA KLUCZOWE: rynek mocy, rozproszone źródła energii, odnawialne źródła energii, rynek energii, klastry energii 
